\title{
Carbapenemase-producing Enterobacteriaceae: Overview of a major public health challenge
}

\author{
Entérobactéries et carbapénémases : bilan et enjeux d'un problème de santé publique majeur \\ P. Nordmann ${ }^{\mathrm{a}, \mathrm{b}, *}$ \\ a Inserm U914, Kremlin-Bicêtre, France \\ ${ }^{\mathrm{b}}$ Unité de microbiologie médicale et moléculaire, département de médecine, faculté des sciences, université de Fribourg, Fribourg, Switzerland
}

\begin{abstract}
Bacterial resistance to antibiotics has become a major source of concern for public health. Enterobacteriaceae are among the most common human pathogens, causing community-acquired as well as hospital-acquired infections. Carbapenem-resistant Enterobacteriaceae have been increasingly reported worldwide since their first identification more than 20 years ago. Three main classes of carbapenemases have been identified: Ambler class A beta-lactamase (KPC), class B (metallo-enzymes), and class D (OXA-48 type). Klebsiella pneumoniae carbapenemases (KPC) was first reported in the United States in the late 1990s and since then worldwide, with a marked endemicity in the United States, Greece, and now Italy. Carbapenemase NDM-1 (New Delhi metallo-beta-lactamase-1) is one of the most recently reported metallo-enzymes. It has spread widely in the Indian sub-continent and now worldwide. Carbapenemases of the oxacillinase-48 type (OXA-48) have been identified mostly in Mediterranean and southern European countries with a rapid spread. An early and quick identification of carbapenemase-producing infected patients, but also of carriers, is mandatory to prevent the spread of these highly resistant pathogens. The early identification of carriers and implementing of cohorting strategies is the only means to prevent nosocomial outbreaks caused by carbapenemase, with very few, if any, therapeutic options.
\end{abstract}

Keywords: Enterobacteriaceae; Carbapenemase; Metallo-beta-lactamase; Oxacillinase OXA-48; New Delhi metallo-beta-lactamase-1; Klebsiella pneumoniae carbapenemase

\section{Résumé}

La résistance bactérienne aux antibiotiques est d'incidence croissante notamment parmi les entérobactéries qui sont les bactéries pathogènes les plus fréquentes pour l'Homme et sont la source de nombreuses infections communautaires et nosocomiales. Des entérobactéries résistantes aux carbapénèmes ont été rapportées avec une fréquence croissante dans le monde depuis leur première description il y a plus de 20 ans. Trois principales classes de carbapénémases ont été décrites : classe A (KPC), classe B (métallo-enzymes) et classe D (OXA-48). Depuis leur première description aux États-Unis à la fin des années 1990, les carbapénémases Klebsiella pneumoniae (KPC) ont été observées sur les cinq continents. La plus forte endémicité se situe aux États-Unis, en Grèce, et plus dernièrement en Italie. Parmi les carbapénémases du groupe des métallo-enzymes, New Delhi metallo-beta-lactamase-1 (NDM-1) est de description plus récente. Elle a une prévalence très élevée dans l'ensemble du sous-continent indien. Les carbapénémases de type oxacillinase-48 (OXA-48) ont été rapportées essentiellement dans le pourtour de la Méditerranée et en Europe du Sud où leur diffusion est particulièrement rapide. Pour prévenir l'extension de la diffusion de ces bactéries pathogènes multirésistantes, l'identification précoce et rapide des sujets infectés, mais aussi des patients porteurs, devient une nécessité. Elle permet la mise en œuvre d'une stratégie d'isolement par cohorting qui représentent l'unique moyen d'éviter la propagation d'épidémies nosocomiales causées par des souches productrices de carbapénémases, pour lesquelles les possibilités thérapeutiques sont limitées.

Mots clés : Entérobactéries; Carbapénémases; Métallo-ß-lactamase ; Oxacillinase-48; New Delhi metallo-beta-lactamase-1 ; Klebsiella pneumoniae carbapénémase

* Correspondence.

E-mail address: patrice.nordmann@unifr.ch 
Bacterial resistance to antibiotics has become a major source of concern for public health. The reality of this menace was fully acknowledged by world decision makers in 2013 at the Davos Economic Forum (Switzerland). With as subtitle "Health and hubris", the global press release at the end of this forum presents the size of the risk in the following terms "Huge strides forward in health have left the world dangerously complacent. Rising resistance to antibiotics could push overburdened health systems to the brink, while a hyper-connected world allows pandemics to spread. This risk case draws on the connections between antibiotic resistance, chronic disease and the failure of the international intellectual property regime, recommending more international collaboration and different funding models". The risk for Europe was assessed financially at 1.5 billion euros. The severity of this menace is amplified by the fact that research for new antibiotic agents is currently stalled. It may be possible that no totally new agent active against multiresistant bacteria will be put on the market in a close future. The 20th century was "the century of antibiotics", marked by the discovery and the continuous development of new more and more active antibiotics, but no new family has been available for clinicians since lipopeptides in 1987.

Virologists have discovered numerous viruses in the previous 3 decades: HIV, hepatitis virus, SARS, or the new flu viruses; at the same time many agents active on some of these viruses were developed and the antiviral therapeutic arsenal has never stopped growing. Conversely, in bacteriology, we have selected strains resistant to all antibiotics among the most frequent bacterial species — Enterobacteriaceae — without being able to develop agents capable of destroying them or effective strategies to prevent their extension. These carbapenemase-producing Enterobacteriaceae are progressively spreading throughout the world [1].

\section{General features and classification}

The enterobacterial carbapenemases differ from the extended spectrum beta-lactamases (ESBL) which include (CTX-M), which hydrolyze or inactivate the beta-lactams and 2nd and 3 rd generation cephalosporins, but not carbapenems. Most carbapenemases hydrolyze beta-lactams and cephalosporins, but also monobactams and carbapenems, so that no beta-lactam can remain effective (Fig. 1).

The Ambler classification proposed in 1980 is based on analogies of the peptide sequence; beta-lactamases are classified in 4 groups, A to D. Groups A, C, and D enzymes are serine-enzymes, while those of group B are metallo-enzymes. Carbapenemases mainly belong to 3 great groups of beta-lactamases, A, B, and D, the differences of which have not only a genetic and biochemical interest, but also a clinical one, because the profile of resistance and the epidemiology of these strains differ.

The first group, called Ambler class A, is that of penicillinases. The most common is KPC (Klebsiella pneumoniae carbapenemase), but there are others, such as Serratia Marcescens (SME), non-metallo carbapanemase (NMC), imipenemase (IMI), Guyana extended-spectrum-lactamase (GES), etc. First identified in the 1980s, they are enzymes the activity spectrum

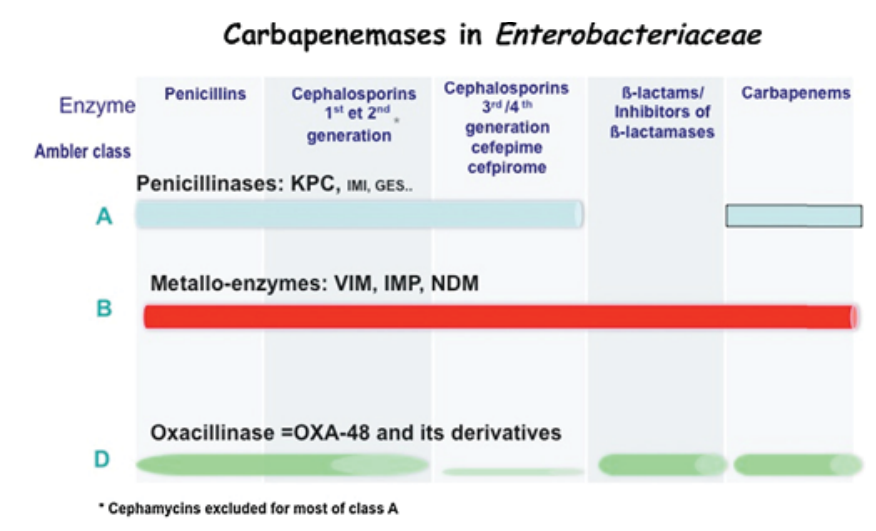

Fig. 1. Activity spectrum of carbapenemases in Enterobacteriaceae. Spectre d'activité des carbapénémases des entérobactéries.

of which extends to carbapenems. They remain inhibited, at least in vitro, by beta-lactamase inhibitors, especially clavulanic acid.

The second group, class B, is that of metallo-proteins, one of the latest of with a large spread is NDM-1. These metalloproteins hydrolyze all antibiotics, except aztreonam. The third group, class $\mathrm{D}$, is that of oxacillinases, OXA-48 derivatives. They hydrolyze penicillins, 1st generation cephalosporins, and carbapenems; they are resistant to beta-lactamase inhibitors, and weakly active against 2 nd and 3rd generation cephalosporins such as cefotaxime or ceftazidime, and hydrolyze only partly carbapenems.

None of the beta-lactamase inhibitors currently available, nor even the new inhibitors under development, allow inhibiting the 3 groups of carbapenemases.

\section{Group of penicillinases: KPC}

The term KPC, for K. pneumoniae carbapenemase, is relatively inadequate because these are enzymes the genes of which transfer very easily from an enterobacterium to another, whatever the type, and thus are not limited to K. pneumoniae. The strains expressing KPC are resistant to all beta-lactams, but also resistant to most of the other antibiotics families.

Class A carbapenemases have been identified sporadically in clinical isolates clinical since the 1980s; they were most often chromosomal enzymes. A strain carrying a plasmid carbapenemase, KPC-1, was first observed in North Carolina in 1996 [2]. KPC strains remained rare in the USA until 2005, when KPC-producing Enterobacteriaceae were identified in outbreaks, in several New York and New Jersey hospitals. A spread was then observed throughout North America [3,4]. In 2012, more than 1,200 strains of $K$. pneumoniae producing KPC type enzymes were isolated from blood cultures in a New York teaching hospital, proving their large spread (P. Nordmann, personal communication). This menace has now been taken into account at the highest level in the USA where major research grants have been attributed by the federal authorities to fight against this major public healthcare challenge.

KPC strains have spread largely, as all enteric bacteria, via colonized patients and air transportation [5]. After the East coast of the USA, KPC plasmid strains were isolated almost 
everywhere in the world: in France for the first time in 2005 in a patient coming back from New York where he had undergone bilateral nephrostomy [6]; in Israel [7,8]; in China and Taiwan [9,10]; in South America: in Columbia in a Pseudomonas aeruginosa strain [11], in Brazil [12,13], in Argentina [14]...) and of course in most European countries [15]. The main endemic focus in Europe is located in Greece [15-17]. Italy, affected shortly after Greece, comes second [18], but Scotland [19], Germany [20], Belgium [21], Finland [22], Scandinavian countries [23], Switzerland [24] are also affected, via Greece and Italy most often. Most of the colonized patients reported in France come from Italy [25]. Nevertheless, at this time, there are few epidemic foci in France and their extension is limited.

There are many circulating strains, even if some clones are rather predominant, especially ST type ST-258. The genes carrying resistance enzymes are located on transposons, which give them an additional degree of bacterial plasticity [26].

\section{Metallo-enzymes}

One of the currently best known metallo-beta-lactamases is NDM-1 (for New Delhi metallo-beta-lactamase), described for the first time in 2009 in a Swedish patient of Indian origin, hospitalized in Sweden after coming back from New Delhi [27]. The K. pneumoniae strain was isolated in urine. The NDM strains are usually resistant to almost all antibiotics, except to tigecycline and colistin. British authors were able to determine that the main reservoirs of these resistant strains were located in the Indian sub-continent: India, Pakistan, Bangladesh, and Sri Lanka. These beta-lactamases were later identified in various species of Enterobacteriaceae: not only Klebsiella, but also Escherichia coli, the most frequent of communityacquired Enterobacteriaceae, in Acinetobacter baumannii, then in $P$. aeruginosa. A significant spread, even if more limited, was observed in Great Britain, which has close bonds with India and Pakistan [28,29]. The publication of these results was considered as possibly detrimental for the Indian economy, since managing foreign patients is an important source of revenue. A British television journalist collected samples in New Delhi at water delivery points. The analysis of these samples proved that tap water (including drinkable tap water) and rainwater contained bacteria carrying NDM-1, not only Enterobacteriaceae, Stenotrophomonas maltophilia, and Pseudomonas strains, but also choleric vibrions [30].

Why did these strains appear in the Indian sub-continent and now reached such a high prevalence? In fact, all the factors possibly promoting this emergence can be found.

First, strong selection pressure: all antibiotics are sold freely in India and their use is rarely controlled. India is today the first nation for the production of generic drugs in the world. Generic ertapenem and imipenem manufactured locally are easily available. The reported consumption of carbapenems per capita in India is 8 times higher than that of the Netherlands; the true consumption is probably 25 times higher.

Second, the environment is characterized by the non-respect of elementary hygiene rules, especially concerning water. A great proportion of people present with chronic diarrhea and the mortality due to intestinal infections is one of the highest in the world.

Third, the transmission and spread of strains is promoted by over-population: 1.4 billion people live in India in slightly more than 3 million $\mathrm{km}^{2}, 6$ times the size of France. This promiscuity enhances the risks of person-to-person transmission of intestinal bacteria. The high temperatures and high humidity are especially favorable for bacterial overgrowth, especially in the south of the country.

The spread of strains in the community is important, so that colonization of travellers is possible even if they were not in direct contact with healthcare. The spread of carbapenemaseproducing strains is currently massive in the Indian subcontinent: the prevalence of carriage is estimated at 5 to $15 \%$ [31].

The impact of intercontinental travels is well illustrated by the epidemiology: the spread of NDM-1 strains overlaps almost exactly the contours of the old British Empire where many Indian or Pakistani expatriate live: Great Britain, Canada, the USA, South Africa, Kenya, Saudi Arabia, Gulf countries, Malaysia, Australia, etc. [32,33]. This is the case especially in English-speaking Africa whereas French-speaking regions are still relatively not affected, likewise in Spanish-speaking countries of South America.

In Europe and especially in France, several NDM-1 strains, most coming from the Indian reservoir, have been identified [34,35]. Even if the rare NDM-1 strains identified in France are not a public healthcare challenge yet, the emergence of K. pneumoniae NDM-1 strains without any link with the Indian sub-continent has already been reported in France and in Morocco [36,37]. Is this an isolated phenomenon or the beginning of a broader spread of these strains? A worldwide spread of these NDM strains, similar to those observed within a few years for the ESBL producing strains of the CTX-M type would be a catastrophe.

Besides K. pneumoniae and E. coli, NDM producing strains have been identified in many bacterial species: Enterobacter, Serratia, Citrobacter, Pseudomonas, Acinetobacter, etc. These are not particularly virulent strains; asymptomatic carriage may persist for more than a year, but severe invasive, septicemia or neurosurgical infections may develop and raise unsolvable therapeutic issues.

The may concern with NDM resistance is that it is now carried by E. coli, ubiquitous and non-nosocomial bacterium, the most frequent of all bacteria, the first pathogen responsible for community-acquired infections, the first cause of urinary tract infections and bacterial diarrhea [28]. Controlling such community-acquired bacteria is almost impossible. A hospital can be closed but not community life.

Genetically, these strains can associate up to 20 determinants of chromosomal plasmid resistance [38].

\section{Group of OXA-48-type oxacillinases}

Oxacillinases (Ambler class D) account for the greatest number of multiresistant strains currently detected in France. The genes come from plasmids and strains may host several 


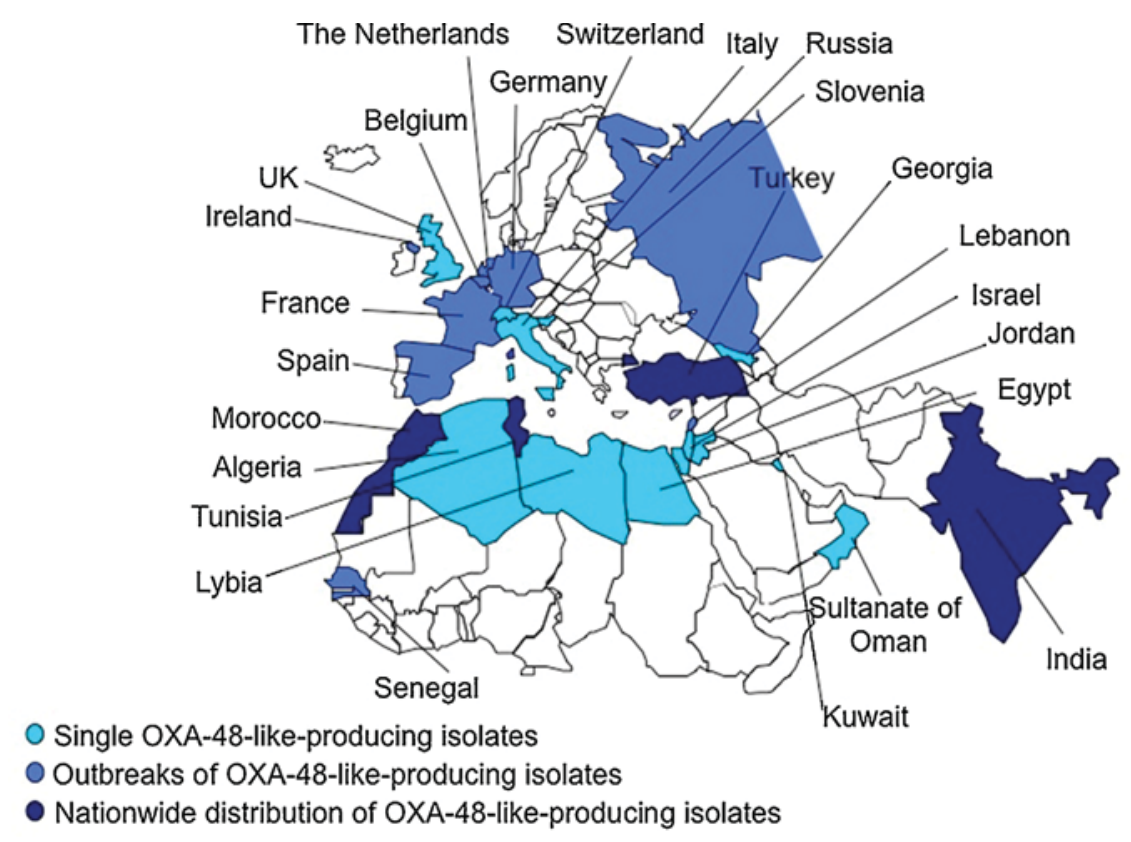

Fig. 2. Worldwide spread of OXA-48 producing strains. Diffusion des souches OXA-48 dans le monde.

resistance genes, especially OXA-48 and CTX-M. The contamination reservoir is in this case much closer to France, in North Africa, Libya, Egypt, the Middle East, and Turkey. There are increased risks related to political and sanitary upheavals in these countries (Fig. 2). The historical and political bonds between France and these nations explain the important spread of these strains in our country.

The OXA-48 gene is very unusually (in bacteriology) most often located on a single plasmid, which has spread in many different Enterobacteriaceae strains and species [39].

\section{Avoiding the Italian scenario}

In 2012, the French National Reference Center (Bicêtre) identified 343 strains producing a carbapenemase among the 1,485 strains received with a more or less marked resistance to carbapenems. Most of them were Klebsiella, but also E. coli (Fig. 3). This evolution is a matter of concern since it proves the extrahospital spread. Resistance is primarily of the OXA-48 type (75\%), and less frequently KPC (12\%) and NDM (8\%). Carbapenemases Verona imipenemase (VIM) $(5 \%)$ and IMI $(<1 \%)$ remain a minority.

The objective for France is to avoid the Italian scenario, where was observed in 2010 the very rapid spread of resistant strains (source: European Center for Disease Prevention and Control; Antimicrobial resistance surveillance in Europe 2010. Annual report. EARS-Net. ECDC, 2011). Before, in 2009, these strains were isolated almost exclusively in Greece, and in 2010 the rate of resistant strains rose from less than $5 \%$ to more than 10 and $25 \%$, within a year. All Italian hospitals — in Rome, Milan, Verona, Venice - now have to face the endemicity of KPC strains [15]. It is thus most important that any patient hospitalized in Italy be screened on admission in the French hospital system [40].

\section{Rapid diagnosis}

The implementation of screening and isolation measures is all the more effective if the diagnosis of colonization is made early. The Carba NP test, a rapid diagnostic test, was developed by our team [41]. It is a simple colorimetric test that identifies any carbapenemase activity. The technique is very easy to implement and does not require molecular biology. Hence it is cheap ( 2 to 3 euros) and may be developed in any country or structure with limited resources. The result is obtained in less than 2 hours, with a specificity and a sensitivity of $100 \%$, which is rare for a biological test. The Carba NP test has been adopted

\section{Resistance to antibiotics CNR-Bicêtre}

2012

\begin{tabular}{lc}
\hline OXA-48 & 257 \\
KPC & 40 \\
NDM & 26 \\
VIM & 18 \\
IMP & 0 \\
IMI & 2 \\
\hline Total & 343 \\
\hline
\end{tabular}

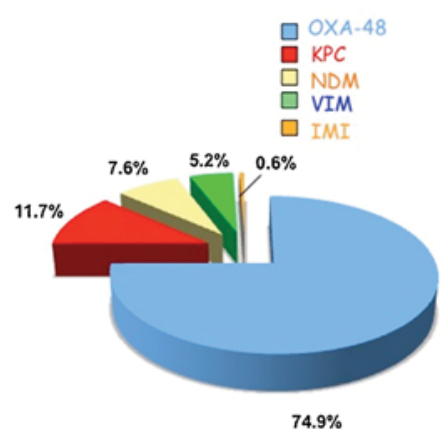

Fig. 3. Carbapenemase-producing strains in France in 2012. Souches productrices de carbapénémases en France en 2012. French National Reference Center, Bicêtre 
already in several countries, France, Singapore, Hong Kong, Italy, Belgium, Great Britain, Germany, Switzerland, the Mayo Clinic (USA), etc.

\section{Perspectives}

Even if we refuse to consider the catastrophe scenario, the prospects for antibiotherapy in the next 3 years are relatively pessimistic. Contrary to what was observed for Staphylococcus aureus, the reversion of Enterobacteriaceae resistance seems to be extremely rare or null. What may be feared is the evolution from multiple resistances to panresistance. And there is a well-demonstrated relationship between antibiotic resistance and increased mortality of infection. Furthermore, the aging population, the development of intensive care, of organ transplantations, of anticancerous treatments are all factors leading to an increase of immunodepression, making patients ideal targets for carbapenemase-producing Enterobacteriaceae. These are evolving from the status of strictly nosocomial to that of community-acquired bacteria, rendering no-effective isolation measures applied only on healthcare institutions.

Policies for the controlled use of anti-infectious drugs remain mandatory to try to stop the hospital spread of these multiresistant bacteria, but hygiene measures at the source of prevention of cross transmission are capital. All hospitalized patients coming from a foreign country than transferred to the French healthcare system should be screened. Cohorting procedures should be implemented as early as possible and very strictly as soon as they are indicated. It is highly probable that specialized units will soon have to be set up in the large hospitals, with a strict geographic separation and dedicated personnel. These multidrug resistant bacteria should be managed like the SARS virus or flu mutants; it is a public healthcare obligation. These multidrug resistant bacteria should be considered with the utmost caution, even if Enterobacteriaceae bacterial species are well known (E. coli, K. pneumoniae, etc.) and belong for the greater number to the commensal flora.

\section{The dangers of hubris on human health}

Health is a critical system that is constantly being challenged, be it by emerging pandemics or chronic illnesses. Scientific discoveries and emerging technologies allow us to face such challenges, but the medical successes of the past century may also be creating a false sense of security. Arguably, one of the most effective and common means to protect human life - the use of antibacterial and antimicrobial compounds (antibiotics) - may no longer be readily available in the near future. Every dose of antibiotics creates selective evolutionary pressures, as some bacteria survive to pass on the genetic mutations that enabled them to do so. Until now, new antibiotics have been developed to replace older, increasingly ineffective ones. However, human innovation may no longer be outpacing bacterial mutation. None of the new drugs currently in the development pipeline may be effective against certain new mutations of killer bacteria that could turn into a pandemic. Are there ways to stimulate the development of new antibiotics as well as align incentives to prevent their overuse, or are we in danger of returning to a pre-antibiotic era in which a scratch could be potentially fatal?

Global Risks 2013 report of the World Economic Forum. Full report available at http://www.weforum.org/globalrisks2013.

\section{Disclosure of interest}

The author declares that he has no conflicts of interest concerning this article.

\section{References}

[1] Nordmann P, Dortet L, Poirel L. Carbapenem resistance in Enterobacteriaceae: here is the storm! Trends Mol Med 2012;18:263-72.

[2] Yigit H, Queenan AM, Anderson GJ, Domenech-Sanchez A, Biddle JW, et al. Novel carbapenem-hydrolyzing beta-lactamase, KPC-1, from a carbapenem-resistant strain of Klebsiella pneumoniae. Antimicrob Agents Chemother 2001;45:1151-61

[3] Bratu S, Landman D, Haag R, Recco R, Eramo A, Alam M, et al. Rapid spread of carbapenem-resistant Klebsiella pneumoniae in New York City: a new threat to our antibiotic armamentarium. Arch Intern Med 2005; 165:1430-5.

[4] Landman D, Bratu S, Kochar S, Panwar M, Trehan M, Doymaz M, et al. Evolution of antimicrobial resistance among Pseudomonas aeruginosa, Acinetobacter baumannii and Klebsiella pneumoniae in Brooklyn, NY. J Antimicrob Chemother 2007;60:78-82.

[5] Dortet L, Radu I, Gautier V, Blot F, Chachaty E, Arlet G. Intercontinental travels of patients and dissemination of plasmid-mediated carbapenemase KPC-3 associated with OXA-9 and TEM-1. J Antimicrob Chemother 2008;61:455-7.

[6] Naas T, Nordmann P, Vedel G, Poyart C. Plasmid-mediated carbapenemhydrolyzing beta-lactamase KPC in a Klebsiella pneumoniae isolate from France. Antimicrob Agents Chemother 2005;49:4423-4.

[7] Navon-Venezia S, Chmelnitsky I, Leavitt A, Schwaber MJ, Schwartz D, Carmeli Y. Plasmid-mediated imipenem-hydrolyzing enzyme KPC-2 among multiple carbapenem-resistant Escherichia coli clones in Israel. Antimicrob Agents Chemother 2006;50:3098-101.

[8] Leavitt A, Navon-Venezia S, Chmelnitsky I, Schwaber MJ, Carmeli Y. Emergence of KPC-2 and KPC-3 in carbapenem-resistant Klebsiella pneumoniae strains in an Israeli hospital. Antimicrob Agents Chemother 2007;51:3026-9.

[9] Wei ZQ, Du XX, Yu YS, Shen P, Chen YG, Li LJ. Plasmid-mediated KPC-2 in a Klebsiella pneumoniae isolate from China. Antimicrob Agents Chemother 2007;51:763-5.

[10] Chung KP, Tseng SP, Huang YT, Tsai TH, Teng LJ, Hsueh PR. Arrival of Klebsiella pneumoniae carbapenemase (KPC)-2 in Taiwan. J Antimicrob Chemother 2011;66:1182-4.

[11] Villegas MV, Lolans K, Correa A, Kattan JN, Lopez JA, Quinn JP, et al. First identification of Pseudomonas aeruginosa isolates producing a KPC-type carbapenem-hydrolyzing beta-lactamase. Antimicrob Agents Chemother 2007;51:1553-5. 
[12] Monteiro J, Santos AF, Asensi MD, Peirano G, Gales AC. First report of KPC-2-producing Klebsiella pneumoniae strains in Brazil. Antimicrob Agents Chemother 2009;53:333-4.

[13] Chang MR, Biberg CA, Lopes FA, Tetila AF, Pignatari AC. The first report of infection with Klebsiella pneumoniae carrying the bla kpc gene in State of Mato Grosso do Sul, Brazil. Rev Soc Bras Med Trop 2013;46:114-5.

[14] Gomez SA, Pasteran FG, Faccone D, Tijet N, Rapoport M, Lucero C, et al. Clonal dissemination of Klebsiella pneumoniae ST258 harbouring KPC-2 in Argentina. Clin Microbiol Infect 2011;17:1520-4.

[15] Cantón R, Akóva M, Carmeli Y, Giske CG, Glupczynski Y, Gniadkowski M, et al. Rapid evolution and spread of carbapenemases among Enterobacteriaceae in Europe. Clin Microbiol Infect 2012;18:413-31.

[16] Tsakris A, Kristo I, Poulou A, Markou F, Ikonomidis A, Pournaras S. First occurrence of KPC-2-possessing Klebsiella pneumoniae in a Greek hospital and recommendation for detection with boronic acid disc tests. J Antimicrob Chemother 2008;62:1257-60.

[17] Cuzon G, Naas T, Demachy MC, Nordmann P. Plasmid-mediated carbapenem-hydrolyzing beta-lactamase KPC-2 in Klebsiella pneumoniae isolate from Greece. Antimicrob Agents Chemother 2008;52:796-7.

[18] Fontana C, Favaro M, Sarmati L, Natoli S, Altieri A, Bossa MC, et al. Emergence of KPC-producing Klebsiella pneumoniae in Italy. BMC Res Notes 2010;3:40.

[19] Palepou MFI, Woodford N, Hope R, Colman M, Glover J, Kaufmann ME, et al. Novel class A carbapenemase, KPC-4, in an Enterobacter isolate from Scotland. In: 15th European Congress of Clinical Microbiology and Infectious Diseases (ECCMID). 2005. P427.

[20] Wendt C, Schütt S, Dalpke AH, Konrad M, Mieth M, Trierweiler-Hauke B, et al. First outbreak of Klebsiella pneumoniae carbapenemase (KPC)producing K. pneumoniae in Germany. Eur J Clin Microbiol Infect Dis 2010;29:563-70.

[21] Bogaerts P, Montesinos I, Rodriguez-Villalobos H, Blairon L, Deplano A, Glupczynski Y. Emergence of clonally related Klebsiella pneumoniae isolates of sequence type 258 producing KPC-2 carbapenemase in Belgium. J Antimicrob Chemother 2010;65:361-2.

[22] Österblad M, Kirveskari J, Hakanen AJ, Tissari P, Vaara M, Jalava J. Carbapenemase-producing Enterobacteriaceae in Finland: the first years (2008-11). J Antimicrob Chemother 2012;67:2860-4.

[23] Samuelsen $\varnothing$, Naseer U, Tofteland S, Skutlaberg DH, Onken A, Hjetland $\mathrm{R}$, et al. Emergence of clonally related Klebsiella pneumoniae isolates of sequence type 258 producing plasmid-mediated KPC carbapenemase in Norway and Sweden. J Antimicrob Chemother 2009;63:654-8.

[24] Babouee B, Widmer AF, Dubuis O, Ciardo D, Droz S, Betsch BY, et al. Emergence of four cases of KPC-2 and KPC-3-carrying Klebsiella pneumoniae introduced to Switzerland, 2009-10. Euro Surveill 2011;16(11) [PII: 19817].

[25] Cuzon G, Naas T, Demachy MC, Nordmann P. Nosocomial outbreak of Klebsiella pneumoniae harbouring bla(KPC-3) in France subsequent to a patient transfer from Italy. Int J Antimicrob Agents 2012;39:448-9.

[26] Petrella S, Ziental-Gelus N, Mayer C, Renard M, Jarlier V, Sougakoff W. Genetic and structural insights into the dissemination potential of the extremely broad-spectrum class A beta-lactamase KPC-2 identified in an Escherichia coli strain and an Enterobacter cloacae strain isolated from the same patient in France. Antimicrob Agents Chemother 2008;52: 3725-36.

[27] Yong D, Toleman MA, Giske CG, Cho HS, Sundman K, Lee K, et al. Characterization of a new metallo-beta-lactamase gene, $b l a_{(\mathrm{NDM}-1)}$, and a novel erythromycin esterase gene carried on a unique genetic structure in Klebsiella pneumoniae sequence type 14 from India. Antimicrob Agents Chemother 2009;53:5046-54.

[28] Poirel L, Hombrouck-Alet C, Freneaux C, Bernabeu S, Nordmann P. Global spread of New Delhi metallo- $\beta$-lactamase 1. Lancet Infect Dis 2010;10:832.

[29] Kumarasamy KK, Toleman MA, Walsh TR, Bagaria J, Butt F, Balakrishnan $\mathrm{R}$, et al. Emergence of a new antibiotic resistance mechanism in India, Pakistan, and the UK: a molecular, biological, and epidemiological study. Lancet Infect Dis 2010;10:597-602.

[30] Walsh TR, Weeks J, Livermore DM, Toleman MA. Dissemination of NDM1 positive bacteria in the New Delhi environment and its implications for human health: an environmental point prevalence study. Lancet Infect Dis 2011;11:355-62.

[31] Perry JD, Naqvi SH, Mirza IA, Alizai SA, Hussain A, Ghirardi S, et al. Prevalence of faecal carriage of Enterobacteriaceae with NDM-1 carbapenemase at military hospitals in Pakistan, and evaluation of two chromogenic media. J Antimicrob Chemother 2011;66:2288-94.

[32] Poirel L, Lagrutta E, Taylor P, Pham J, Nordmann P. Emergence of metallob-lactamase-NDM-1-producing multidrug resistant Escherichia coli in Australia. Antimicrob Agents Chemother 2010;54:4914-6.

[33] Bushnell G, Mitrani-Gold F, Mundy LM. Emergence of New Delhi metallo- $\beta$-lactamase type 1-producing Enterobacteriaceae and nonEnterobacteriaceae: global case detection and bacterial surveillance. Int J Infect Dis 2013;17:e325-33.

[34] Struelens MJ, Monnet DL, Magiorakos AP, Santos O'Connor F, Giesecke J, European NDM-1 Survey Participants. New Delhi metallo-beta-lactamase 1-producing Enterobacteriaceae: emergence and response in Europe. Euro Surveill 2010;15(46) [PII: 19716].

[35] Zarfel G, Hoenigl M, Leitner E, Salzer HJ, Feierl G, Masoud L, et al. Emergence of New Delhi metallo- $\beta$-lactamase, Austria. Emerg Infect Dis 2011;17:129-30.

[36] Nordmann P, Couard JP, Sansot D, Poirel L. Emergence of an autochthonous and community-acquired NDM-1-producing Klebsiella pneumoniae in Europe. Clin Infect Dis 2012;54:150-1.

[37] Poirel L, Benouda A, Hays C, Nordmann P. Emergence of NDM-1producing Klebsiella pneumoniae in Morocco. J Antimicrob Chemother 2011;66:2781-3.

[38] Poirel L, Bonnin RA, Nordmann P. Analysis of the resistome of a multidrugresistant NDM-1-producing Escherichia coli strain by high-throughput genome sequencing. Antimicrob Agents Chemother 2011;55:4224-9.

[39] Poirel L, Bonnin RA, Nordmann P. Genetic features of the widespread plasmid coding for the carbapenemase OXA-48. Antimicrob Agents Chemother 2012;56:559-62.

[40] Poirel L, Potron A, Nordmann P. OXA-48-like carbapenemases: the phantom menace. J Antimicrob Chemother 2012;67:1597-606.

[41] Nordmann P, Poirel L, Dortet L. Rapid detection of carbapenemaseproducing Enterobacteriaceae. Emerg Infect Dis 2012;18:1503-7. 